\title{
Variation in environmental characteristics of waters among Amazon coast oyster culture units
}

\author{
Dioniso de Souza SAMPAIO ${ }^{1 *}$, , Maria de Lourdes Souza SANTOS ${ }^{2}$, Claudia Helena TAGLIAROํ, Colin \\ Robert BEASLEY ${ }^{1}$ \\ Universidade Federal do Pará, Campus de Bragança, Instituto de Estudos Costeiros, Laboratório de Conservação da Biodiversidade e das Águas, Alameda Leandro \\ Ribeiro s/n, Bairro Aldeia, 68.600-000 Bragança, Pará, Brazil \\ Universidade Federal Rural da Amazônia, Instituto Sócio Ambiental e Recursos Hídricos, Av. Presidente Tancredo Neves 2501, Bairro Terra Firme, 66.077-530 \\ Belém, Pará, Brazi \\ *Corresponding author: sampaiods@ufpa.br; (D) https://orcid.org/0000-0002-2688-6001
}

\begin{abstract}
Oyster culture has benefited traditional coastal communities along the Amazon macrotidal mangrove coast of Pará state in Brazil since 2006. Currently, seven oyster culture units in five municipalities are expanding production, but with no environmental monitoring, which is important for the control of the impacts of oyster culture on waters as well as for oyster management and conservation. Seasonal variation in environmental characteristics of the water was evaluated at all oyster culture units in Pará, from September to November 2013 (dry season) and February to April 2014 (wet season), to generate baseline data to evaluate future impacts and aid strategic planning, such as diversifying seed production. Salinity, dissolved oxygen, $\mathrm{pH}$, oxidation-reduction potential, depth, temperature, and chlorophyll- $a$ concentration were measured during flooding and ebbing tides, and compared between seasons and among culture units using uni- and multivariate statistics. All variables were significantly higher in the dry season, except depth, which was significantly greater in the wet season. Mean salinity, which varied from 2.4 to 46, explained most of the variation among culture units in relation to season, sampling date within each season and tidal state. However, dissolved oxygen, $\mathrm{pH}$ and depth were also important. Oyster culture units in Pará may be suitable for sustainable harvesting of seed/spat from the wild (lower salinity and $\mathrm{pH}$ ), or for on-growing (higher salinity, higher $\mathrm{pH}$, and greater depth). Seasonal variation is sufficient to allow both activities at most units at appropriate times of the year, which would help increase oyster production in Pará.
\end{abstract}

KEYWORDS: tropical mariculture, Crassostrea, salinity, water quality

\section{Variação nas características ambientais de águas entre unidades de cultivo de ostras na costa amazônica}

\section{RESUMO}

A ostreicultura beneficia comunidades costeiras tradicionais ao longo da costa do manguezal de macro-marés amazônico do Estado do Pará no Brasil desde 2006. Atualmente, sete cultivos em cinco municípios expandem sua produção, mas sem monitoramento ambiental, importante para verificar impactos da ostreicultura sobre as águas, mas também para o manejo e conservação de ostras. A variação sazonal nas características ambientais da água foi avaliada em todos os cultivos do Pará, de setembro a novembro de 2013 (estação seca) e fevereiro a abril de 2014 (estação chuvosa), para gerar dados de base para avaliar futuros impactos e ajudar no planejamento estratégico, como a diversificação da produção de sementes. Salinidade, oxigênio dissolvido, $\mathrm{pH}$, potencial de oxidação-reduçáo, profundidade, temperatura e concentração de clorofila- $a$ foram medidas durante as marés inundantes e vazantes, e comparadas entre estaçóes e unidades de cultivo usando estatísticas uni- e multivariadas. Todas as variáveis foram significativamente mais elevadas na estação seca, exceto profundidade, que foi significativamente maior na estação chuvosa. Salinidade média, que variou de 2,4 a 46, explicou a maior parte da variação entre as unidades de cultivo em relação à estação, data de amostragem dentro de cada estação e estado das marés. No entanto, oxigênio dissolvido, pH e profundidade também foram importantes. As unidades de cultivo de ostras no Pará são apropriadas para colheita sustentável de sementes na natureza (menor salinidade e $\mathrm{pH}$ ) ou para engorda (maior salinidade, maior $\mathrm{pH}$ e maior profundidade). A variação sazonal permite ambas atividades na maioria das unidades, no período apropriado do ano, e ajudaria a aumentar a produção de ostras no Pará.

PALAVRAS-CHAVE: maricultura tropical, Crassostrea, salinidade, qualidade da água 


\section{INTRODUCTION}

Physical-chemical variation in water is relevant for oyster culture in Brazil and the National Council for the Environment (CONAMA, resolution 357/05) determines limits to dissolved oxygen, $\mathrm{pH}$, and other parameters in waters destined for fisheries and aquaculture (CONAMA 2005). Since 2006, mangrove oysters, Crassostrea gasar (Deshayes, 1830) are cultured at seven units in five municipalities (Sampaio et al. 2019): Augusto Corrêa, Salinópolis, Maracaná, Curuçá and São Caetano de Odivelas (Figure 1), along the eastern sector of the coast of Pará state, Brazil, where salinity varies from 0 to 40 (Rosa-Filho et al. 2018). See Sampaio et al. (2019) for detailed socioeconomic information on the culture units. Mangrove oysters in Pará are grown mainly using bag culture on tables, but also suspended culture using long-lines at a unit in Augusto Corrêa. One unit in Curuça is the only one in Brazil where oyster seed is harvested from the wild for sale to other units for on-growing (Sampaio et al. 2019).

The Amazon mangrove coast is relatively conserved (Ferreira and Lacerda 2016) and the oyster culture sector is growing in terms of culture unit size and oyster production (Sampaio et al. 2019). Mangrove oyster culture generates income and employment for traditional communities, as well as for associated services in the region, such as transport, supplies, tourism and restaurants (Sampaio et al. 2019). However, coastal urban development threatens South American oyster diversity and stocks (Carranza et al. 2009) and there is no environmental monitoring of waters around Pará culture units.

Sustainable planning and management of oyster culture requires environmental monitoring (Alleway et al. 2016). Water temperature, dissolved oxygen, salinity and degree of submersion, among other variables, are used as input for the assessment of habitat suitability for oyster bed rehabilitation and/or restoration (Walles et al. 2016) and environmental impacts of oyster culture (Lunstrum et al. 2018; Turner et al. 2019). Although selected physical-chemical variables have been examined in relation to oyster reproduction, survival and growth at some units in Pará (Paixão et al. 2013; Funo et al. 2015; Oliveira et al. 2018), as well as trace elements at all units in the peak wet and dry months (Silva et al., 2018), no standardized study of a more diverse range of variables has been undertaken at all units. The dynamics of life history parameters of C. gasar are highly seasonal and associated with temperature, salinity, $\mathrm{pH}$, dissolved oxygen, degree of submersion and microalgal concentrations for larval settlement, juvenile and adult survival and/or growth (Nascimento 1991; Lemos et al. 1994; Ramos and Castro 2004; Alvarenga and Nalesso 2006; Lopes et al. 2013; Funo et al. 2015; Funo et al. 2019; Legat et al. 2017a,b; Oliveira et al. 2018) and reproduction (Christo and Absher 2006; Paixão et al. 2013; Ramos et al. 2013; Gomes et al. 2014).

We evaluated the seasonal variation in environmental variables at all seven mangrove oyster culture units along the eastern sector of the Pará coast during the dry and wet seasons. We aimed at providing baseline data to evaluate future impacts from increasing urban development on the Amazon coast (Szlafsztein 2012), and expansion of the oyster culture sector itself, supporting strategic planning for the sector, such as the urgent need to diversify oyster seed supply in Pará (Sampaio et al. 2019).

\section{MATERIAL AND METHODS}

\section{Data collection}

Fieldwork took place at each of the seven oyster culture units from September to November 2013 and from February to April 2014. The oyster culture units are established as associations of local producers: Associação de Mulheres na

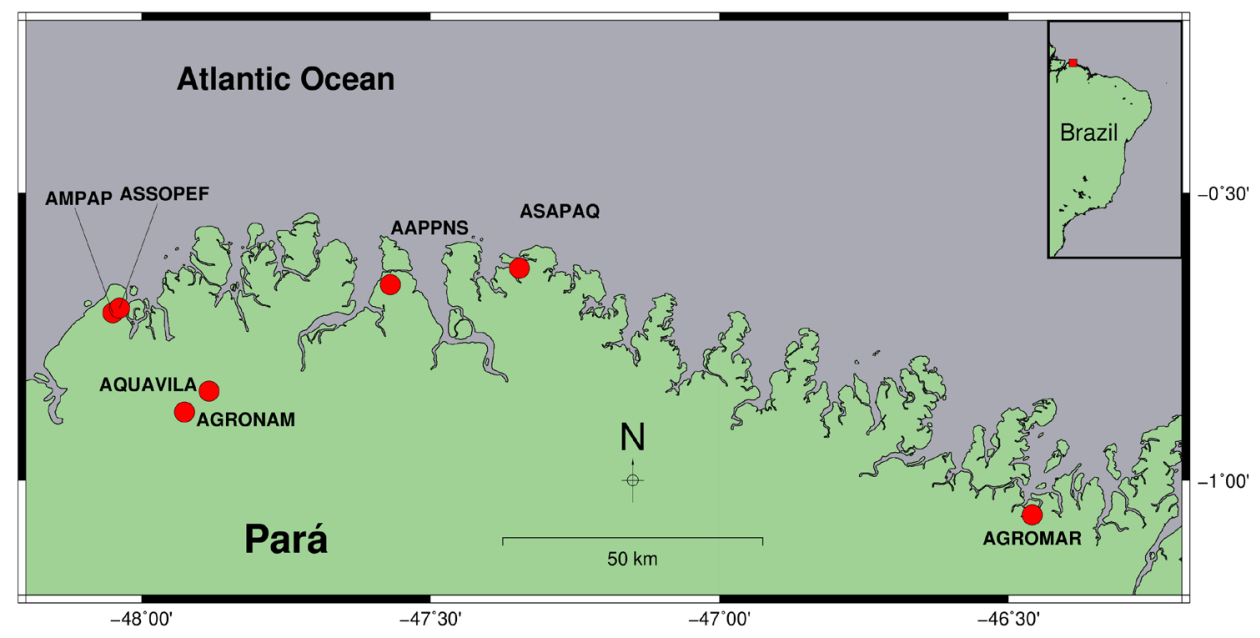

Figure 1. Location of the seven oyster (Crassostrea gasar) culture associations (AMPAP, ASSOPEF, AQUAVILA, AGRONAM, AAPPNS, ASAPAQ and AGROMAR) along the northeastern coast of Pará state, Brazil. This figure is in color in the electronic version. 
Pesca e Agricultura de Pererú, (AMPAP) and Associação dos Produtores de Ostras de Pererú de Fátima (ASSOPEF), both in the municipality of São Caetano de Odivelas, Associação de Aquicultores da Vila de Lauro Sodré (AQUAVILA) and Associação Agropesqueira de Nazaré de Mocajuba (AGRONAM), in Curuça, Associação dos Aquicultores, Produtores Rurais e Pescadores de Nazaré do Seco (AAPPNS), in Maracanã, Associação dos Agricultores e Aquicultores de Santo Antônio de Urindeua (ASAPAQ), in Salinópolis, and Associação dos Agricultores e Aquicultores de Nova Olinda, (AGROMAR), in Augusto Corrêa. The sampling periods were defined on the basis of monthly accumulated rainfall $(\mathrm{mm})$ at automatic weather stations of the National Institute of Meteorology in northeastern Pará (A202 Castanhal, A215 Salinópolis and A226 Bragança), and the definition of the regional dry and wet seasons, based on long term (30 year) rainfall data (Moraes et al. 2005).

In both seasons, all seven oyster culture units were visited during the flooding and/or ebbing tide, during the full or new moon. Data were recorded at the beginning, middle and end of each tidal phase (flooding or ebbing) in each of three equidistant areas at each culture unit. Thus, sampling in each of three months (September to November and February to April) with three tidal replicates and three culture unit replicates resulted in 27 replicates for each of the seven culture units in each season (dry, wet), resulting in a total of 378 observations.

Salinity, temperature $\left({ }^{\circ} \mathrm{C}\right)$, oxidation-reduction potential $(\mathrm{mV}), \mathrm{pH}$ and dissolved oxygen $\left(\mathrm{mg} \mathrm{l}^{-1}\right)$ were measured in situ (three randomly positioned replicates within each culture unit at the depth at which the oysters were being cultured) with a digital probe (HANNA HI-9828). Water depth (m) was measured with a digital echo sounder (Speedtech SM5). Chlorophyll-a concentration $\left(\mathrm{mg} \mathrm{m}^{-3}\right)$ was measured only in November 2013 and April 2014, and determined 36 hours after transport of refrigerated water samples to the laboratory by extraction of pigments with 90\% acetone (Teixeira 1973).

\section{Data treatment and analysis}

Differences in mean values of each variable among culture units and in each season were evaluated using Analysis of Variance (ANOVA), followed by a Tukey's Honestly Significant Difference post hoc comparison of pairwise differences, wherever a significant group difference was found. Posterior diagnostic analysis of residuals was used to verify if ANOVA assumptions of residual normality and homogeneity were met. Otherwise, ANOVA was rerun on appropriately transformed observations. Only one $\log _{10}$ transformation was needed for dissolved oxygen $\left(\mathrm{mg} \mathrm{l}^{-1}\right)$.

Multivariate ordination of replicates from each culture unit in each season was carried out using non-metric multidimensional scaling (NMDS) on a distance matrix calculated using Euclidean distance from the environmental variables using the metaMDS function in the package vegan (Oksanen et al. 2019). The variables significantly associated with the NMDS ordination of replicates were selected using the envfit function, also in vegan. Multivariate differences among culture units, sampling date (month) and tide (flooding, ebbing) were tested by using permutational multivariate analysis of variance (Permanova), using the function adonis in vegan. All data were analyzed using GNU $\mathrm{R}$ version 3.5.2 (R Core Team 2018) and are available online (Sampaio et al. 2020).

\section{RESULTS}

\section{Univariate variation among culture units and between seasons}

Salinity, dissolved oxygen, $\mathrm{pH}$, temperature and oxidationreduction potential, as well as chlorophyll- $a$ measured in November 2013 and April 2014, decreased significantly from the dry to the wet season, whereas depth increased (Table 1; Figures $2-4$ ). All variables differed significantly among culture units (Table 1), except for oxidation-reduction potential.

Mean salinity was significantly higher in the dry season (Figure 2a; Table 1) being lowest at AGRONAM (11.5) and AQUAVILA (22.7), both in Curuça and with high freshwater input from the Mocajuba River, followed by AMPAP and ASSOPEF. Mean salinity was highest (above 40) at AAPPNS, ASAPAQ and AGROMAR, further east. In contrast, in the wet season (Figure 2a), mean salinity was similar $(2.4-8.1)$ at all culture units, except AGROMAR (13.9). Seasonal differences were large at all sites, except at AGRONAM and AQUAVILA, resulting in significant interaction between season and culture unit (Figure 2a; Table 1).

Dissolved oxygen was significantly higher in the dry season and means ranged from $1.8 \mathrm{mg} \mathrm{l}^{-1}$ at AQUAVILA to $4.2 \mathrm{mg} \mathrm{l}^{-1}$ at AAPPNS (Figure 2b; Table 1). Mean values were intermediate $\left(2.1-3.0 \mathrm{mg} \mathrm{l}^{-1}\right)$ at the other culture units. In the wet season, mean dissolved oxygen concentrations were low (Figure 2b) but similar at most culture units (0.7 - 1.6 $\left.\mathrm{mg}^{-1}\right)$ and highest at AGROMAR $\left(3.0 \mathrm{mg} \mathrm{l}^{-1}\right)$. There was significant interaction (Table 1 ) due to very small seasonal differences at AQUAVILA and AGROMAR, and very large differences at AAPPNS and ASAPAQ in relation to other culture units (Figure 2b).

Mean pH was significantly higher in the dry season and differed among culture units (Figure 3a; Table 1). Significant interaction was due to very low seasonal variation at AAPPNS in relation to other culture units. In both seasons, mean $\mathrm{pH}$ was lowest at AGRONAM and AQUAVILA, varying from 6.7 to 6.9 and 7.4 to 7.6 in the dry and wet season, respectively (Figure 3a). At other culture units, $\mathrm{pH}$ ranged from 7.9 to 8.3, and 7.1 to 7.9 , in the dry and wet season, respectively. 
Table 1. Summary of analyses of variance (Anova) testing for differences in mean values of salinity, $\log _{10}$ dissolved oxygen $\left(\mathrm{mg} \mathrm{l}^{-1}\right), \mathrm{pH}$, depth $(\mathrm{m})$, temperature $\left({ }^{\circ} \mathrm{C}\right)$, chlorophyll-a $\left(\mathrm{mg} \mathrm{m}^{-3}\right)$ and oxidation-reduction potential $(\mathrm{mV})$ measured at all seven oyster culture units along the Pará coast during the 2013 dry season (September to November) and the 2014 wet season (February to April). Note differences in $\mathrm{df}$ for the smaller number of observations of chlorophyll- $a$ and dissolved oxygen. Chlorophyll-a values were measured only in November 2013 and April 2014. Abbreviations: $\mathrm{df}=$ degrees of freedom; SS = Sum of Squares; MS $=$ Mean Square. Some dissolved oxygen measurements were recorded as missing values due to equipment malfunction, mainly in the wet season.

\begin{tabular}{lccccc}
\hline Source of variation & df & SS & MS & F & P \\
\hline Salinity & & & & & \\
Culture unit & 6 & 16541 & 2757 & 107.57 & $<0.001$ \\
\hline Season & 1 & 64196 & 64196 & 2504.98 & $<0.001$ \\
\hline Culture unit $\times$ Season & 6 & 10038 & 1673 & 65.28 & $<0.001$ \\
\hline Residuals & 364 & 9328 & 26 & & \\
log $_{10}$ Dissolved oxygen $\left(\mathbf{m g ~ I}^{-1}\right)$ & & & & \\
\hline Culture unit & 6 & 0.756 & 0.1259 & 3.071 & $<0.01$ \\
\hline Season & 1 & 2.837 & 2.8373 & 69.188 & $<0.001$ \\
\hline Culture unit $\times$ Season & 6 & 1.753 & 0.2921 & 7.123 & $<0.001$ \\
\hline Residuals & 313 & 12.835 & 0.0410 & & \\
\hline
\end{tabular}

$\mathrm{pH}$

\begin{tabular}{lccccc|} 
Culture unit & 6 & 45.569 & 7.595 & 74.7661 & $<0.001$ \\
\hline Season & 1 & 32.331 & 32.331 & 318.2832 & $<0.001$ \\
\hline Culture unit $\times$ Season & 6 & 3.337 & 0.556 & 5.4754 & $<0.001$ \\
Residuals & 364 & 36.975 & 0.102 & & \\
\hline
\end{tabular}

Depth (m)

\begin{tabular}{lccccc} 
Culture unit & 6 & 133.99 & 22.3321 & 9.7275 & $<0.001$ \\
\hline Season & 1 & 15.73 & 15.7260 & 6.8499 & 0.01 \\
\hline Culture unit × Season & 6 & 2.89 & 0.4814 & 0.2097 & 0.97 \\
Residuals & 364 & 835.66 & 2.2958 & &
\end{tabular}

Temperature $\left({ }^{\circ} \mathrm{C}\right)$

\begin{tabular}{lccccc} 
Culture unit & 6 & 50.229 & 8.371 & 18.631 & $<0.001$ \\
\hline Season & 1 & 188.963 & 188.963 & 420.544 & $<0.001$ \\
\hline Culture unit $\times$ Season & 6 & 31.368 & 5.228 & 11.635 & $<0.001$ \\
\hline Residuals & 364 & 163.556 & 0.449 & &
\end{tabular}

Chlorophyll- $a\left(\mathrm{mg} \mathrm{m}^{-3}\right)$

\begin{tabular}{lccccc} 
Culture unit & 6 & 69.90 & 11.65 & 15.70 & $<0.001$ \\
\hline Month & 1 & 220.43 & 220.43 & 296.95 & $<0.001$ \\
\hline Culture unit × Month & 6 & 92.04 & 15.34 & 20.66 & $<0.001$ \\
Residuals & 111 & 82.40 & 0.74 & &
\end{tabular}

\section{Oxidation-reduction potential $(\mathrm{mV})$}

\begin{tabular}{lccccc} 
Culture unit & 6 & 14352 & 2392 & 2.0317 & 0.06 \\
\hline Season & 1 & 196746 & 196746 & 167.1117 & $<0.001$ \\
\hline Culture unit × Season & 6 & 12625 & 2104 & 1.7873 & 0.10 \\
\hline Residuals & 364 & 428549 & 1177 & & \\
\hline
\end{tabular}
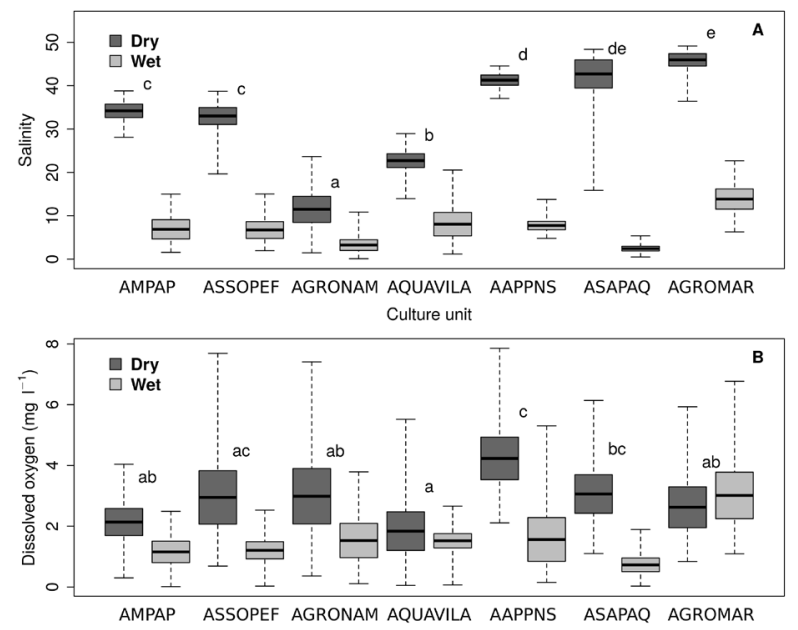

Culture unit

Figure 2. Salinity (A) and dissolved oxygen $\left(\mathrm{mg} \mathrm{l}^{-1}\right)(B)$ measured at all seven oyster culture units along the Pará coast during the 2013 dry season (September to November) and the 2014 wet season (February to April).Values are the minimum and maximum (whiskers) and the mean $\pm 95 \%$ confidence interval (horizontal line and box). Differences between culture units are significant where letters differ
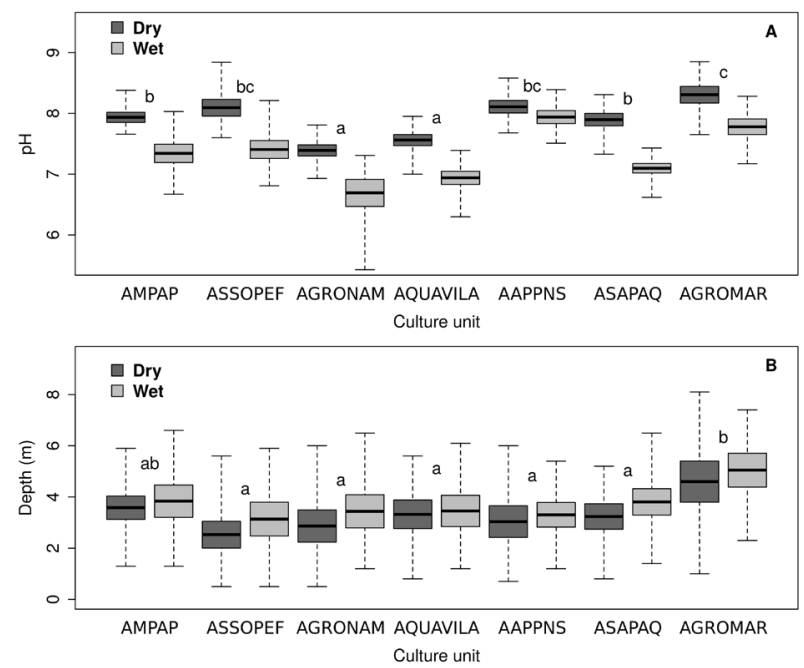

Figure 3. $\mathrm{pH}(\mathrm{A})$ and depth (B) measured at all seven oyster culture units along the Pará coast during the 2013 dry season (September to November) and the 2014 wet season (February to April).Values are the minimum and maximum (whiskers) and the mean $\pm 95 \%$ confidence interval (horizontal line and box). Differences between culture units are significant where letters differ

Mean depth was significantly greater in the wet season (Figure 3b; Table 1). Variation among culture units was remarkably low in each season (Figure $3 \mathrm{~b}$ ), although interaction was significant (Table 1) due to the very small seasonal difference at AQUAVILA in relation to the other culture units. In both seasons, mean depth was lowest and relatively similar at ASSOPEF, AGRONAM, AQUAVILA and AAPPNS $(2.5-3.4 \mathrm{~m})$, slightly greater at AMPAP and ASAPAQ $(3.2-3.8 \mathrm{~m})$, and greatest at AGROMAR (4.6 $5.0 \mathrm{~m}$ ) (Figure 3b).

Mean temperature was significantly higher in the dry season (Figure 4a, Table 1) during which temperature was 

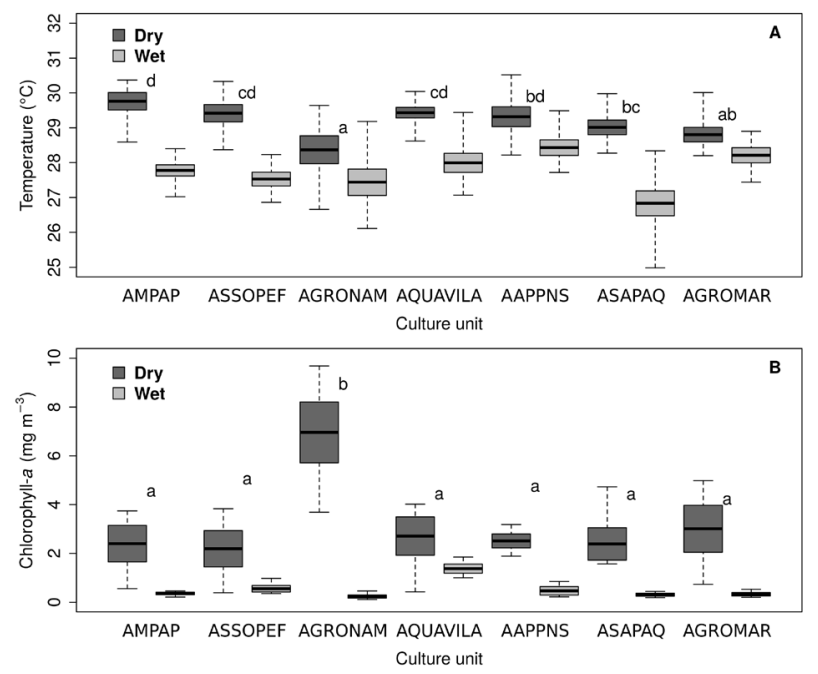

Figure 4. Temperature (A) and chlorophyll-a (B) measured at all seven oyster culture units along the Pará coast during the 2013 dry season (September to November) and the 2014 wet season (February to April). Chlorophyll-a values were measured only in November 2013 and April 2014. Values are the minimum and maximum (whiskers) and the mean $\pm 95 \%$ confidence interval (horizontal line and box). Differences between culture units are significant where letters differ.

lowest at AGRONAM $\left(28.4^{\circ} \mathrm{C}\right)$ and AGROMAR $\left(28.8^{\circ} \mathrm{C}\right)$ and was slightly higher $\left(29.0-29.8^{\circ} \mathrm{C}\right)$ at other culture units (Figure 4a). In the wet season, mean temperature was lowest at ASAPAQ $\left(26.8^{\circ} \mathrm{C}\right)$, intermediate at AMPAP, ASSOPEF and AGRONAM $\left(27.4-27.8^{\circ} \mathrm{C}\right)$, and highest at AQUAVILA, AAPPNS and AGROMAR $\left(27.9-28.2^{\circ} \mathrm{C}\right)$. Seasonal differences in temperature were lowest at AGRONAM, AAPPNS and AGROMAR, but were much greater at the other sites, especially ASAPAQ, leading to significant interaction (Figure 4a; Table 1).

Mean chlorophyll- $a$ values were significantly higher in November 2013 (end of dry season) than in April 2014 (end of wet season) (Figure $4 \mathrm{~b}$; Table 1). Mean chlorophyll-a values ranged between 2.2 and $3.0 \mathrm{mg} \mathrm{m}^{-3}$ among culture units in November 2013, with the exception of AGRONAM where there was an exceptionally high mean value of $6.96 \mathrm{mg} \mathrm{m}^{-3}$. In the wet season, mean chlorophyll- $a$ values were very low $\left(<0.6 \mathrm{mg} \mathrm{m}^{-3}\right)$ at all culture units, except at AQUAVILA (1.4 $\mathrm{mg} \mathrm{m}^{-3}$ ) (Figure $4 \mathrm{~b}$ ).

Mean oxidation-reduction potential was always negative, significantly more so in the wet season but did not differ among culture units $(P=0.06)$, nor was there significant interaction (Table 1). Mean values ranged between -100.1 to $-123.7 \mathrm{mV}$ in the dry season and between -144.7 to $-175.4 \mathrm{mV}$ in the wet season with a tendency to be less negative from west to east, especially in the dry season. As oxidation-reduction potential explained little variation among culture units, this variable was excluded from further analyses. Additionally, as chlorophyll- $a$ values were measured only in
November 2013 and April 2014, these also could not be included in multivariate analyses.

\section{Dry season multivariate trend}

In the dry season, the greatest significant multivariate differences in environmental characteristics of the water, based on pseudo- $F$ and $r^{2}$ values, were found among culture units (Table 2, Figure 5a). All environmental variables were significantly associated with the dry season multivariate ordination of culture unit replicates (Figure 5a; Table 3), the stress of which was $2.09 \%$, indicating an excellent twodimensional representation of the data. Salinity $\left(\mathrm{r}^{2}=0.9999\right)$, dissolved oxygen $\left(r^{2}=0.8504\right)$ and $\mathrm{pH}\left(\mathrm{r}^{2}=0.5353\right)$ explained the largest amount of variation among culture unit replicates (Table 3; Supplementary Material, Figures S1 - S3). Salinity increased from west to east along the distribution of the
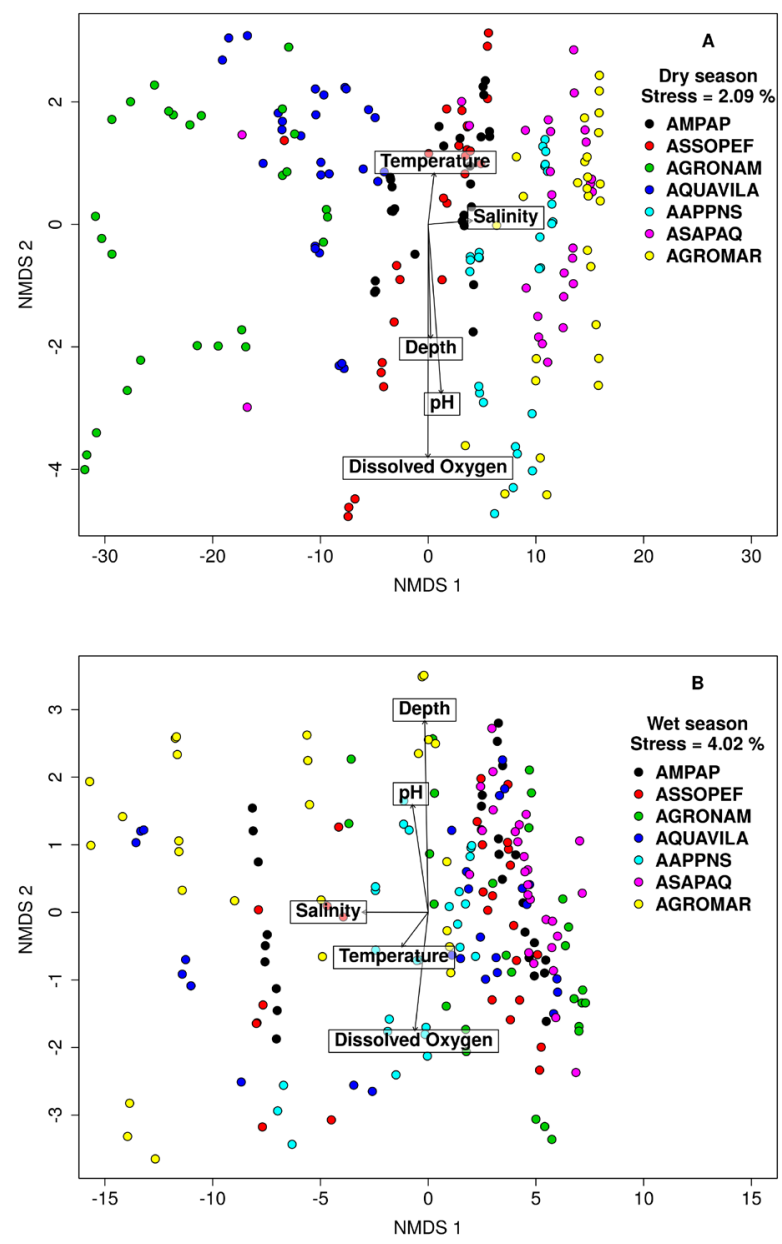

Figure 5. Non-metric multidimensional scaling of seven oyster culture units along the Pará coast based on salinity, temperature $\left({ }^{\circ} \mathrm{C}\right)$, oxidation-reduction potential $(\mathrm{mV}), \mathrm{pH}$, depth $(\mathrm{m})$, and dissolved oxygen $\left(\mathrm{mg} \mathrm{l}^{-1}\right)$ during the 2013 dry season (September, October and November) (A) and the 2014 wet season (February, March and April) (B). Superimposed vectors show variables that are significantly correlated with the pattern of replicates in each season. Vector length is proportional to the degree of association. Replicates are coded according to culture unit. This figure is in color in the electronic version. 
Table 2. Summary of permutational multivariate analyses of variance (Permanova) testing for multivariate differences among culture units, sampling dates (months) and tidal state while sampling, based on values of salinity, dissolved oxygen $\left(\mathrm{mg} \mathrm{l} \mathrm{l}^{-1}\right), \mathrm{pH}$, depth $(\mathrm{m})$ and temperature $\left({ }^{\circ} \mathrm{C}\right)$ measured at all seven oyster culture units along the Pará coast during the 2013 dry season (September to November) and the 2014 wet season (February to April). Abbreviations: df = degrees of freedom; SS $=$ Sum of Squares; MS = Mean Square.

\begin{tabular}{|c|c|c|c|c|c|c|c|c|c|c|c|}
\hline \multirow{2}{*}{ Source of variation } & \multicolumn{6}{|c|}{ Dry } & \multicolumn{5}{|c|}{ Wet } \\
\hline & df & SS & MS & $\mathrm{F}$ & $R^{2}$ & $P$ & SS & MS & $\mathrm{F}$ & $\mathrm{R}^{2}$ & $P$ \\
\hline Culture units & 6 & 24531.1 & 4088.5 & 179.804 & 0.7929 & 0.001 & 242646 & 404.40 & 58.435 & 0.3387 & 0.001 \\
\hline Month & 2 & 1963.7 & 981.8 & 43.178 & 0.0635 & 0.001 & 1964.6 & 982.30 & 141.939 & 0.2742 & 0.001 \\
\hline Tide & 1 & 65.1 & 65.1 & 2.865 & 0.0021 & 0.080 & 270.6 & 270.62 & 39.104 & 0.0378 & 0.001 \\
\hline Culture units $\times$ Month & 11 & 554.9 & 50.4 & 2.218 & 0.0179 & 0.014 & 1340.2 & 121.84 & 17.605 & 0.1870 & 0.001 \\
\hline Residuals & 168 & 3820.1 & 22.7 & & 0.1235 & & 1162.7 & 6.92 & & 0.1623 & \\
\hline Total & 188 & 30934.9 & & & 1.0000 & & 7164.5 & & & 1.0000 & \\
\hline
\end{tabular}

Table 3. Associations $\left(r^{2}\right)$ between environmental variables and the ordination by multidimensional scaling (Envfit) of replicates, and their significance $(P)$, based on values of salinity, dissolved oxygen $\left(\mathrm{mg} \mathrm{l}^{-1}\right), \mathrm{pH}$, depth $(\mathrm{m})$ and temperature $\left({ }^{\circ} \mathrm{C}\right)$ measured at all seven oyster culture units along the Pará coast during the 2013 dry season (September to November) and the 2014 wet season (February to April).

\begin{tabular}{lcccc}
\hline \multirow{2}{*}{ Variable } & \multicolumn{2}{c}{ Dry } & \multicolumn{2}{c}{ Wet } \\
\cline { 2 - 5 } & $r^{2}$ & $P$ & $r^{2}$ & $P$ \\
\hline Salinity & 0.9999 & 0.0001 & 0.9983 & 0.0001 \\
\hline Dissolved oxygen $\left(\mathrm{mg} \mathrm{I}^{-1}\right)$ & 0.8504 & 0.0001 & 0.3690 & 0.0001 \\
$\mathrm{pH}$ & 0.5353 & 0.0001 & 0.3305 & 0.0001 \\
Depth $(\mathrm{m})$ & 0.2070 & 0.0001 & 0.8633 & 0.0001 \\
Temperature $\left({ }^{\circ} \mathrm{C}\right)$ & 0.0609 & 0.0033 & 0.1891 & 0.0001 \\
\hline
\end{tabular}

culture units from the freshwater-influenced culture units at AGRONAM and AQUAVILA, through intermediate salinities at AMPAP and ASSOPEF to the more easterly highsalinity culture units of AAPPNS, ASAPAQ and AGROMAR (Figures 5a; Supplementary Material, Figure S1a). Dissolved oxygen concentrations clearly decreased from September to November (Supplementary Material, Figure S2a) associated with increasing temperature. Although $\mathrm{pH}$ tended to be higher in September and October, there was wide variation during these months and values were also high in November at AGROMAR (Supplementary Material, Figure S3a). Tidal state was not significantly associated with any of the variables (Table 2), nor the ordination of replicates in the dry season.

\section{Wet season multivariate trend}

In the wet season, the greatest significant multivariate differences in environmental characteristics of the water, based on pseudo- $F$ and $r^{2}$ values, were found among sampling dates (months) (Table 2). All environmental variables were significantly associated with the wet season multivariate ordination of culture unit replicates (Figure 5b; Table 3), the stress of which was $4.02 \%$, indicating an excellent twodimensional representation of the data. Salinity $\left(r^{2}=0.9983\right)$ and depth $\left(r^{2}=0.8633\right)$, and to a lesser degree, dissolved oxygen $\left(r^{2}=0.3690\right)$ and $\mathrm{pH}\left(\mathrm{r}^{2}=0.3305\right)$, explained the greatest amount of variation among the culture unit replicates (Table 3; Supplementary Material, Figures S1 - S3), which was again strongly associated with a gradient of increasing salinity along culture unit locations (Figure 5b). However, among culture units during the wet season, there was greater variation in salinity, which decreased from February-March to April as the rainy season progressed (Supplementary Material, Figure S1b). In the wet season, the culture units with lowest salinity were AGRONAM, ASAPAQ, AQUAVILA, AMPAP and ASSOPEF, through intermediate salinity at AAPPNS to high salinity at the most easterly culture unit AGROMAR (Figure 5b; Supplementary Material, Figure S1b). Flood tides in March and April were associated with higher dissolved oxygen concentrations (Supplementary Material, Figure S2b) and greater depth (Supplementary Material, Figure S3b). However, significant multivariate differences related to tidal state in the wet season had very weak effects $\left(r^{2}=0.03\right.$, Table 2$)$.

\section{DISCUSSION}

\section{Salinity}

Both seasonal freshwater influx and tidal variation, as well as mangrove vegetation and sediments, influence salinity, nutrients and productivity of the Amazon coastal waters (Berrêdo et al. 2008; Santos et al. 2008a,b; Asp et al. 2013; Pamplona et al. 2013). Volume and duration of seasonal rainfall increase from east to west along the Pará coast (Moraes et al. 2005) with associated variation in salinity (Asp et al. 2013). At the oyster culture units, seasonal variation in salinity ranged widely (0.1 to 49.2), due to greater freshwater runoff between February and April (Asp et al. 2013; Monteiro et al. 2016) at AGRONAM and AQUAVILA, and high rates of estuarine evaporation in the dry season (Berrêdo et al. 2008) at AAPPNS, ASAPAQ and AGROMAR. Crassostrea gasar tolerates wide variation in salinity (2-50), but optimal survival is between 4 and 40 (Horodesky et al. 2019). Previous studies have correlated salinity with oyster growth and reproduction. Higher salinity at AGROMAR and ASSOPEF, nearer the coast, was associated with greater oyster growth than at AQUAVILA, which was furthest from the coast (Oliveira $e t$ al. 2018) and, at the AGROMAR unit, oyster reproductive activity was greater during drier periods (Paixão et al. 2013). 
Oyster production per municipality (SEBRAE 2020) in Pará in 2016 (Sampaio et al. 2019) was 20 tons in Salinópolis (ASAPAQ) and 13.2 tons in Augusto Corrêa (AGROMAR), which are more easterly, and have a drier climate and higher salinity, 4.8 tons at the low-salinity, freshwater-influenced Curuçá units (AQUAVILA and AGRONAM), and 3.8 tons at the intermediate salinity units in São Caetano de Odivelas (ASSOPEF and AMPAP). Although water quality is suitable for on-growing, low production at AAPPNS, ASSOPEF and AMPAP is due to relatively low investments in recent years (Sampaio et al. 2019). In Maranhão state, salinity varied between 5 and 37 (Ramos and Castro 2004; Funo et al. 2015) and wild native oyster beds (C. gasar and C. rhizophorae) are more common where salinity ranges annually between 10 and 30 (Funo et al. 2015). At Cananéia, São Paulo state, southeastern Brazil, wild populations of Crassostrea brasiliana (= C. gasar) tolerate salinity between 8 and 34 (Pereira et al. 1988; Pereira and Chagas Soares 1996) but growth is best between 15 and 25 (Nascimento 1991). In Santa Catarina state, southern Brazil, C. gasar grew slightly better in lower salinity (29.2) estuarine waters than in higher salinity (33.6) coastal waters (Lopes et al. 2013).

Salinity was lowest at AGRONAM and AQUAVILA due to freshwater inflow from the Mocajuba river. AQUAVILA, where mean salinity varied seasonally between 8.1 and 22.7, is the major supplier of wild-harvested seed in Pará. Very low salinity $(5-7)$ is associated with poor growth and survival of seed (Funo et al. 2015; Legat et al. 2017b) and adult C. gasar (Oliveira et al. 2018). Survival and growth of C. gasar seed in the laboratory were highest in intermediate salinities $(20-25)$, but remained very high between 10 and 45 (Funo et al. 2015) or tolerated $21-35$ with optimal results at 28 (Legat et al. 2017a). In the field, settlement of mangrove oysters is greater in the dry period, when salinity is high, but growth is higher at low salinity (Funo et al. 2019). In Brazilian mangroves, the abundance of seed of C. rhizophorae and C. gasar declines at salinities below 19 and 25, respectively (Nascimento 1991). AAPPNS and AGRONAM, where median annual salinity ranged from $8-40$ and $3-11$, respectively, have both begun commercial seed harvesting. The annual range of salinity is very wide at all units, and during periods of intermediate salinity there may be potential for seed harvesting, which should be monitored for commercial viability and ecological sustainability. It is important to conserve and manage all wild oyster populations, and diversify seed sources since practically all oyster culture in Pará depends on a single wild population at AQUAVILA (Sampaio et al. 2019).

\section{Temperature}

Temperature differed little among units but greatly between seasons (mean seasonal difference was $1.4^{\circ} \mathrm{C}$ ), reflecting the variation of mean water temperature in the region between 27 and $30{ }^{\circ} \mathrm{C}$ (Berrêdo et al. 2008; Pamplona et al. 2013).
Reproductive development of C. gasar (Gomes et al. 2014; Ramos et al. 2014) and abundance and survival of larvae of C. rhizophorae and C. gasar (Lemos et al. 1994; Christo and Absher 2006) increase with temperature. However, C. gasar has a wide tolerance to temperature in Brazil, being cultured in waters varying from $30^{\circ} \mathrm{C}$ in the north and northeast (Ramos and Castro 2004; Alvarenga and Nalesso 2006; Funo et al. 2015; Legat et al. 2017a) to as low as $15^{\circ} \mathrm{C}$ in the south and southeast (Mignani et al. 2013; Legat et al. 2017a), where selection for local conditions may have improved growth performance (Legat et al. 2017a).

\section{Depth}

AGROMAR is the only oyster culture unit in Pará with a mean depth greater than $4 \mathrm{~m}$ in both the wet and dry seasons, and thus the only unit where on-growing is feasible on both long-line and table systems. Shallower waters at the other six units only allow use of the table system, where growth is slower due to exposure at low tide. Crassostrea gasar growth rates are lower where tidal amplitude is greater (Legat et al. 2017a).

\section{Dissolved oxygen}

Dissolved oxygen concentrations were usually lower than the minimum limit of $5 \mathrm{mg} \mathrm{l}^{-1}$ established by Brazilian legislation for fisheries and aquaculture in estuarine waters (CONAMA 2005), especially in the wet season. Lower regional wet season values (Ramos and Castro 2004; Pamplona et al. 2013; Moura and Nunes 2016) may be due to increased runoff and higher turbidity (Asp et al. 2013) resulting in lower photosynthetic activity, since estuarine dissolved oxygen and chlorophyll- $a$ concentrations are correlated (Pamplona et al. 2013). Low dissolved oxygen concentrations among culture units in our study may be cause for concern as low values, even for short periods, are negatively associated with growth, filtration ability and disease susceptibility in oysters (Jeppesen et al. 2018; Breitburg et al. 2015). Growth of cultured C. gasar is positively associated with salinity and dissolved oxygen and negatively with temperature (Oliveira et al. 2018). Temperature and dissolved oxygen were associated in the dry season in our study, potentially reducing growth at this time. Natural processes such as secondary production of biomass, restricted water exchange, and weather conditions may diminish oxygen produced by photosynthesis and diffusion (Breitburg et al. 2015). Sewage outflow from Amazon coastal settlements (Sousa-Felix et al. 2017), and wet season detritus input and runoff, result in greater estuarine biological oxygen demand as well as a potentially significant public health risk from contamination by microorganisms (Mignani et al. 2013; Monteiro et al. 2016; Sousa-Felix et al. 2017). For example, coliform bacteria increased in waters around mangrove oyster culture units in Iguape, Bahia state, in the rainy season and during spring tides (Freitas et al. 2017). Dissolved oxygen should be monitored regularly and excessive oyster densities 
and low water flow-through should be avoided at on-growing sites.

\section{Chlorophyll-a concentration}

Chlorophyll-a concentrations were much lower in the wet season, when turbidity is often high due to terrestrial and freshwater runoff (Asp et al. 2013), which may limit phytoplankton productivity (Santos et al. 2008a). A very similar pattern in chlorophyll- $a$ values was recorded at oyster culture sites in Maranhão, where mean values were less than $2.0 \mathrm{mg} \mathrm{m}^{-3}$ during the dry season and were between 1.6 and $4.0 \mathrm{mg} \mathrm{m}^{-3}$ during the wet season (Ramos and Castro 2004). Growth rate and development time in cultured $C$. gigas in southern Brazil are associated with chlorophyll-a concentrations with negative effects for young oysters at lower $\left(2.1-3.3 \mathrm{mg} \mathrm{m}^{-3}\right.$ ) ranges (Mizuta et al. 2012).

\section{$\mathrm{pH}$}

Mean $\mathrm{pH}$ values at the culture units were well within the legislation limits of 6.5 - 8.5 (CONAMA 2005) and similar to mean $\mathrm{pH}$ ranges at $C$. gasar culture units in Maranhão (6.82 - 8.16) (Ramos and Castro 2004) and São Paulo (5.89 - 8.26) (Mignani et al. 2013). Values of $\mathrm{pH}$ were lower in the wet season due to freshwater inflow, as determined by Berrêdo et al. (2008) (3.3 - 7.9). Crassostrea gasar cultured in shrimp ponds in northeastern Brazil survived well (67\%), but grew slowly, at $\mathrm{pH}$ around 8.1 (Rosa 2014). In our study, $\mathrm{pH}$ was lowest at AGRONAM and AQUAVILA due to the freshwater influx of the Mocajuba River. Freshwater inflow and rainwater percolation from mangrove sediments may lower $\mathrm{pH}$ in the wet season, whereas marine coastal waters may increase estuarine $\mathrm{pH}$ in the dry season (Berrêdo et al. 2008; Pamplona et al. 2013). Seasonal fluctuations in $\mathrm{pH}$ of coastal and estuarine waters are large, being predicted to increase with ocean acidification, and increasingly lower seasonal values may disrupt oyster reproduction (Boulais et al. 2017). $\mathrm{pH}$ has been positively correlated with dissolved oxygen concentrations at oyster culture units due to the association between $\mathrm{CO}_{2}$ production and $\mathrm{O}_{2}$ consumption during respiration (Breitburg et al. 2015).

\section{CONCLUSIONS}

The first standardized study of environmental characteristics of water among oyster-culture units in Pará state, Brazil showed that water quality is either mostly suitable for ongrowing of juveniles (higher salinity, higher $\mathrm{pH}$, and greater depth) at the more coastal units AMPAP, ASSOPEF, AAPPNS, ASAPAQ and AGROMAR, or for harvesting of wild spat (lower salinity and lower $\mathrm{pH}$ ) at more estuarine, freshwater influenced units AQUAVILA and AGRONAM. Most units have sufficient annual variation in water quality to allow both activities and so increase adult oyster production. There is an urgent need for regular monitoring of salinity, temperature, dissolved oxygen, chlorophyll- $a$ and $\mathrm{pH}$ at oyster culture units in Pará, given the importance of these variables in oyster culture performance, monitoring for public health, and for the rehabilitation and restoration of oyster habitat.

\section{ACKNOWLEDGMENTS}

We are grateful to all the oyster culture units in Pará state for their cooperation and hospitality during fieldwork. This study was financed by Conselho Nacional de Desenvolvimento Científico e Tecnológico (CNPq) and the former Ministério da Pesca e Aquicultura (MPA) via grant \# 406533/2012-1. Fieldwork was carried out under license \# 28304-1 from Instituto Chico Mendes de Conservação da Biodiversidade (ICMBio).

\section{REFERENCES}

Alleway, H.K.; Thurstan, R.H.; Lauer, P.R.; Connell, S.D. 2016. Incorporating historical data into aquaculture planning. ICES Journal of Marine Science, 73: 1427-1436.

Alvarenga, L.; Nalesso, R.C. 2006. Preliminary assessment of the potential for mangrove oyster cultivation in Piraquê-açu river estuary (Aracruz, ES). Brazilian Archives of Biology and Technology, 49: 163-69.

Asp, N.E.; Amorim de Freitas, P.T.; Gomes, V.J.C.; Gomes, J.D. 2013. Hydrodynamic overview and seasonal variation of estuaries at the eastern sector of the Amazonian coast. Journal of Coastal Research, 65: 1092-1097.

Berrêdo, J.F.; Costa, M.L.; Progene, M.d.P.S. 2008. Efeitos das variaçóes sazonais do clima tropical úmido sobre as àguas e sedimentos de manguezais do estuário do rio Marapanim, costa nordeste do Estado do Pará. Acta Amazonica, 38: 473-482.

Boulais, M.; Chenevert, K.J.; Demey, A.T.; Darrow, E.S.; Robison, M.R.; Roberts, J.P. et al. 2017. Oyster reproduction is compromised by acidification experienced seasonally in coastal regions. Scientific Reports, 7: 13276.

Breitburg, D.L.; Hondorp, D.; Audemard, C.; Carnegie, R.B.; Burrell, R.B.; Trice, M.; et al. 2015. Landscape-level variation in disease susceptibility related to shallow-water hypoxia. PLoS ONE 10: e0116223.

Carranza, A.; Defeo, O.; Beck, M. 2009. Diversity, conservation status and threats to native oysters (Ostreidae) around the Atlantic and Caribbean coasts of South America. Aquatic Conservation: Marine and Freshwater Ecosystems, 19: 344-353.

Christo, S.W.; Absher, T.M. 2006. Reproductive period of Crassostrea rhizophorae (Guilding, 1828) and Crassostrea brasiliana (Lamarck, 1819) (Bivalvia : Ostreidae) in Guaratuba Bay, Paraná, Brazil. Journal of Coastal Research, 39: 1215-1218.

CONAMA. 2005. Resolução CONAMA 357, de 17 de março de 2005. Conselho Nacional de Meio Ambiente. (http://www. mma.gov.br/port/conama/res/res05/res35705.pdf). Accessed on 23 Jul 2020.

Ferreira, A.C.; Lacerda, L.D. 2016. Degradation and conservation of Brazilian mangroves, status and perspectives. Ocean \& Coastal Management, 125: 38-46. 
Freitas, F.; Neiva, G.S.; da Cruz, E.S.; Santana, J.d.M.; Mendes da Silva, I.d.M.; Mendonca, F.d.S. 2017. Microbiological quality and environmental factors of estuarine area of Iguape Bay Marine Reserve (Bahia) for cultivation of native oysters. Engenharia Sanitaria e Ambiental, 22: 723-729.

Funo, I.C.S.A.; Antonio, Í.G.; Marinho, Y.F.; Gálvez, A.O. 2015. Influence of salinity on survival and growth of Crassostrea gasar. Boletim do Instituto de Pesca (São Paulo), 41: 837-847.

Funo, I.C.S.A.; Antonio, Í.G.; Marinho, Y.F.; Monteles, J.S.; Lopes, R.G.P.S.; Gálvez, A.O. 2019. Recruitment of oyster in artificial collectors on the Amazon macrotidal mangrove coast. Ciência Rural, 49: e20180482.

Gomes, C.H.A.M.; Silva, F.C.; Lopes, G.R.; Melo, C.M.R. 2014. The reproductive cycle of the oyster Crassostrea gasar. Brazilian Journal of Biology, 74: 967-976.

Horodesky, A.; Castilho-Westphal, G.G.; Cozer, N.; Rossi, V.G.; Ostrensky, A. 2019. Effects of salinity on the survival and histology of oysters Crassostrea gasar (Adanson, 1757) Bioscience Journal, Uberlândia, 35: 586-597.

Jeppesen, R.; Rodriguez, M.; Rinde, J.; Haskins, J.; Hughes, B.; Mehner, L. et al. 2018. Effects of hypoxia on fish survival and oyster growth in a highly eutrophic estuary. Estuaries and Coasts, 41: 89-98.

Legat, J.F.A.; Puchnick-Legat, A.; Fogaça, F.H.d.S.; Tureck, C.R.; Suhnel, S.; de Melo, C.M.R. 2017a. Growth and survival of bottom oyster Crassostrea gasar cultured in the Northeast and South of Brazil. Boletim do Instituto de Pesca (São Paulo), 43: 172-184.

Legat, J.F.A.; Puchnick-Legat, A.; de Miranda Gomes, C.H.A.; Sühnel, S.; de Melo, C.M.R. 2017b. Effects of salinity on fertilization and larviculture of the mangrove oyster, Crassostrea gasar in the laboratory. Aquaculture, 468: 545-548.

Lemos, M.B.N.; Nascimento, I.A.; Araújo, M.M.S.; Pereira, S.A.; Bahia, I.; Smith, D.H. 1994. The combined effects of salinity, temperature, antibiotic and aeration on larval growth and survival of the mangrove oyster, Crassostrea rhizophorae. Journal of Shellfish Research, 13: 187-192.

Lopes, G.R.; Gomes, C.H.A.d.M.; Tureck, C.R.; Melo, C.M.R.d. 2013. Growth of Crassostrea gasar cultured in marine and estuary environments in Brazilian waters. Pesquisa Agropecuária Brasileira, 48: 975-982.

Lunstrum, A.; McGlathery, K.; Smyth, A. 2018. Oyster (Crassostrea virginica) aquaculture shifts sediment nitrogen processes toward mineralization over denitrification. Estuaries and Coasts, 41: 1130-1146.

Mignani, L.; Barbieri, E.; Marques, H.; Oliveira, A. 2013. Coliform density in oyster culture waters and its relationship with environmental factors. Pesquisa Agropecuária Brasileira, 48: 833-840.

Mizuta, D.D.; Júnior, N.S.; Fischer, C.E.; Lemos, D. 2012. Interannual variation in commercial oyster (Crassostrea gigas) farming in the sea (Florianópolis, Brazil, $27^{\circ} 44^{\prime} \mathrm{S}$; $48^{\circ} 33^{\prime}$ W) in relation to temperature, chlorophyll $a$ and associated oceanographic conditions. Aquaculture, 366: 105-114.
Monteiro, M.C.; Jiménez, J.A.; Pereira, L.C.C. 2016. Natural and human controls of water quality of an Amazon estuary (CaetéPA, Brazil). Ocean \& Coastal Management, 124: 42-52.

Moraes, B.C.d.; Costa, J.M.N.d.; Costa, A.C.L.d.; Costa, M.H. 2005. Variação espacial e temporal da precipitação no Estado do Pará. Acta Amazonica, 35: 207-214.

Moura, H.T.G.S.; Nunes, Z.M.P. 2016. Caracterização sazonal das águas do sistema estuarino do Caeté (Bragança-PA). Boletim do Instituto de Pesca (São Paulo), 42: 844-854.

Nascimento, I.A. 1991. Crassostrea rhizophorae (Guilding) and C. brasiliana (Lamarck) in South and Central America. In: Menzel, W. (Ed.). Estuarine and Marine Bivalve Mollusk Culture. v.1. CRC Press, Boca Raton, p.125-134.

Oksanen, J.; Blanchet, F.G.; Friendly, M.; Kindt, R.; Legendre, P.; McGlinn, D. et al. 2019. vegan: Community Ecology Package. R package version 2.5-5, (https://CRAN.R-project. org/package=vegan). Accessed on 23 Jul 2020.

Oliveira, L.F.S.; Ferreira, M.A.P.; Juen, L.; Nunes, Z.M.P.; Pantoja, J.C.D.; da Paixão, L.F. et al. 2018. Influence of the proximity to the ocean and seasonality on the growth performance of farmed mangrove oysters (Crassostrea gasar) in tropical environments. Aquaculture, 495: 661-667.

Paixão, L.; Ferreira, M.A.; Nunes, Z.; Fonseca-Sizo, F.; Rocha, R. 2013. Effects of salinity and rainfall on the reproductive biology of the mangrove oyster (Crassostrea gasar): Implications for the collection of broodstock oysters. Aquaculture, 380-383: 6-12.

Pamplona, F.C.; Paes, E.T.; Nepomuceno, A. 2013. Nutrient fluctuations in the Quatipuru river: A macrotidal estuarine mangrove system in the Brazilian Amazonian basin. Estuarine, Coastal and Shelf Science, 133: 273 - 284.

Pereira, O.M.; Akaboshi, S.; Soares, F.d.C. 1988. Cultivo experimental de Crassostrea brasiliana (Lamarck, 1819) no canal da Bertioga, São Paulo, Brasil (23054’30"S, 4513’42”W). Boletim do Instituto de Pesca (São Paulo), 151: 55-65.

Pereira, O.M.; Soares, F.d.C. 1996. Análise da criação de ostra, Crassostrea brasiliana (Lamarck, 1819) no sítio Guarapari, na região lagunar-estuarina de Cananéia-SP. Boletim do Instituto de Pesca (São Paulo), 23: 135-142.

Ramos, C.d.O.; Ferreira, J.F.; Melo, C.M.R. 2013. Maturation of native oyster Crassostrea gasar at different diets in the laboratory. Boletim do Instituto de Pesca (São Paulo), 39: 107-120.

Ramos, C.d.O.; Gomes, C.H.A.d.M.; Magalhaes, A.R.M.; Santos, A.I.d.; Melo, C.M.R.d. 2014. Maturation of the mangrove oyster Crassostrea gasar at different temperatures in the laboratory. Journal of Shellfish Research, 33: 187-194.

Ramos, R.S.; Castro, A.C.L.d. 2004. Monitoramento das variáveis físico-químicas no cultivo de Crassostrea rhizophorae (Mollusca) (Guilding, 1928) no estuário de Paquatiua - Alcântara/MA, Brasil. Boletim do Laboratório de Hidrobiologia, 17: 29-42.

R Core Team. 2018. R: A Language and Environment for Statistical Computing. R version 3.5.2, (https://www.R-project.org/). Accessed on 23 Jul 2020.

Rosa Filho, J.S.; Pereira, L.C.C.; Aviz, D.; Braga, C.F.; Monteiro, M.C.; da Costa, R.A.M. et al. 2018. Brazilian Estuaries: A 
Benthic Perspective. In: Lana, P.d.C.; Bernardino, A.F. (Ed.). v.1. Springer International Publishing, Heidelberg, p.39-74.

Rosa, L.C.d. 2014. Crescimento e sobrevivência da ostra Crassostrea brasiliana (Lamarck, 1819) mantida em um viveiro de cultivo de camarão. Arquivos de Ciências do Mar, 47: 64-68.

Sampaio, D.d.S.; Santos, M.d.L.S; Tagliaro, C.H.; Beasley, C.R. 2020. Amazon Coast Mangrove Oyster Culture Environmental Data. Figshare. (https://doi.org/10.6084/m9.figshare.12730700). Accessed on 30 Jul 2020.

Sampaio, D.d.S.; Tagliaro, C.H.; Schneider, H.; Beasley, C.R. 2019. Oyster culture on the Amazon mangrove coast: asymmetries and advances in an emerging sector. Reviews in Aquaculture, 11: 88-104.

Santos, M.L.S.; Medeiros, C.; Muniz, K.; Feitosa, F.A.N.; Schwamborn, R.; Macêdo, S.J. 2008a. Influence of the Amazon and Pará rivers on the water composition and phytoplankton biomass on the adjacent shelf. Journal of Coastal Research, 24: 585-593.

Santos, M.L.S.; Muniz, K.; Barros-Neto, B.; Araujo, M. 2008b. Nutrient and phytoplankton biomass in the Amazon River shelf waters. Anais da Academia Brasileira de Ciências, 80: 703-717.

SEBRAE. 2020 Serviço Brasileiro de Apoio às Micro e Pequenas Empresas, Pará. (https://www.sebrae.com.br/sites/PortalSebrae/ ufs/pa). Accessed on 23 Jul 2020.

Silva, R.G.d.; Santos, R.M.; Lima, M.d.O.; dos Santos Mendes, L.d.C.; Castro Mesquita, K.F.; Santos, M.d.LS. 2018. Trace elements in oyster farming areas in the Amazon. Boletim do Instituto de Pesca (São Paulo), 44: e366.

Sousa-Felix, R.C.; Pereira, L.C.C.; Trindade, W.N.; Souza, I.P.d.; Costa, R.M.d.; Jimenez, J.A. 2017. Application of the DPSIR framework to the evaluation of the recreational and environmental conditions on estuarine beaches of the Amazon coast. Ocean \& Coastal Management, 149: 96-106.

Szlafsztein, C.F. 2012. The Brazilian Amazon coastal zone management: implementation and development obstacles. Journal of Coastal Conservation, 16: 335-343.

Teixeira, C. 1973. Introdução aos métodos para medir a produção primária do fitoplâncton marinho. Boletim do Instituto Oceanográfico, São Paulo 22: 59-92.

Turner, J.S.; Kellogg, M.L.; Massey, G.M.; Friedrichs, C.T. 2019. Minimal effects of oyster aquaculture on local water quality: Examples from southern Chesapeake Bay. PLoS ONE, 14: e0224768.

Walles, B.; Fodrie, F.J.; Nieuwhof, S.; Jewell, O.J.D.; Herman, P.M.J.; Ysebaert, T. 2016. Guidelines for evaluating performance of oyster habitat restoration should include tidal emersion: reply to Baggett et al. Restoration Ecology, 24: 4-7.

RECEIVED: 03/02/2020

ACCEPTED: $21 / 07 / 2020$

ASSOCIATE EDITOR: Bruno Spacek Godoy 
SUPPLEMENTARY MATERIAL (only available in the electronic version)

Sampaio et al. Variation in environmental characteristics of waters among Amazon coast oyster culture units.
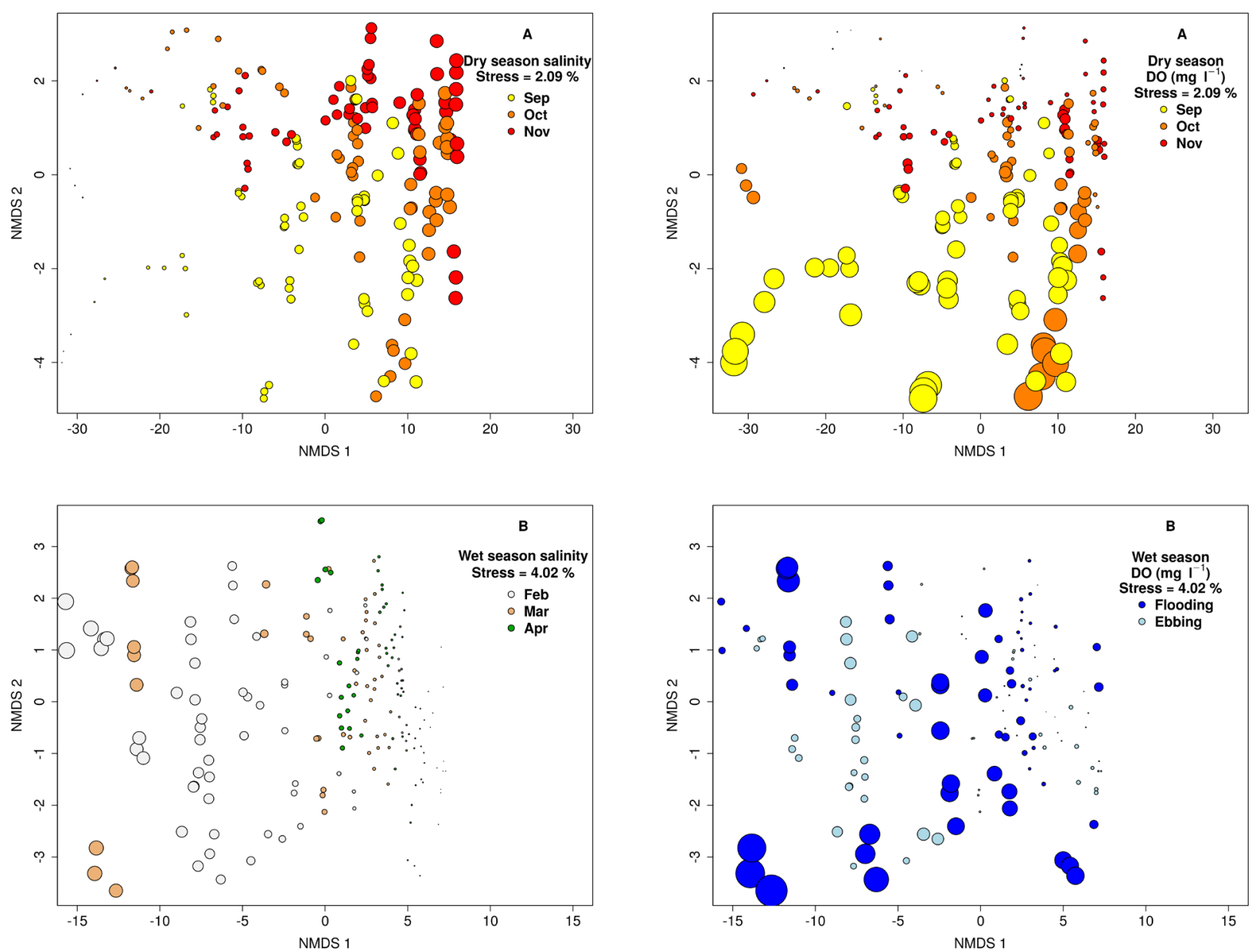

Figure S1. Salinity in relation to non-metric multidimensional scaling of culture units (Figure 5) based on salinity, temperature $\left({ }^{\circ} \mathrm{C}\right)$, oxidation-reduction potential $(\mathrm{mV}), \mathrm{pH}$, depth $(\mathrm{m})$, and dissolved oxygen $\left(\mathrm{mg}^{\mathrm{l}^{-1}}\right)$ at seven oyster culture units along the Pará coast during the 2013 dry season (September, October and November) (A) and the 2014 wet season (February, March and April) (B). Replicates are coded according to sampling date (month) in each season. Diameter of symbols is proportional to the value of salinity measured in each replicate.

Figure S2. Dissolved oxygen $\left(\mathrm{DO}, \mathrm{mg}^{-1}\right)$ in relation to non-metric multidimensional scaling of culture units (Figure 5) based on values of salinity, temperature $\left({ }^{\circ} \mathrm{C}\right)$, oxidation-reduction potential $(\mathrm{mV}), \mathrm{pH}$, depth $(\mathrm{m})$, and dissolved oxygen $\left(\mathrm{mg} \mathrm{l}^{\mathrm{l}^{-1}}\right.$ ) measured at seven oyster culture units along the Pará coast during the 2013 dry season (September, October and November) (A) and the 2014 wet season (February, March and April) (B). Replicates are coded according to sampling date (month) during the dry season in (A) and tidal state (flooding or ebbing) during the wet season in (B). Diameter of symbols is proportional to the value of dissolved oxygen $\left(\mathrm{mg} \mathrm{l}^{-1}\right)$ measured in each replicate. 

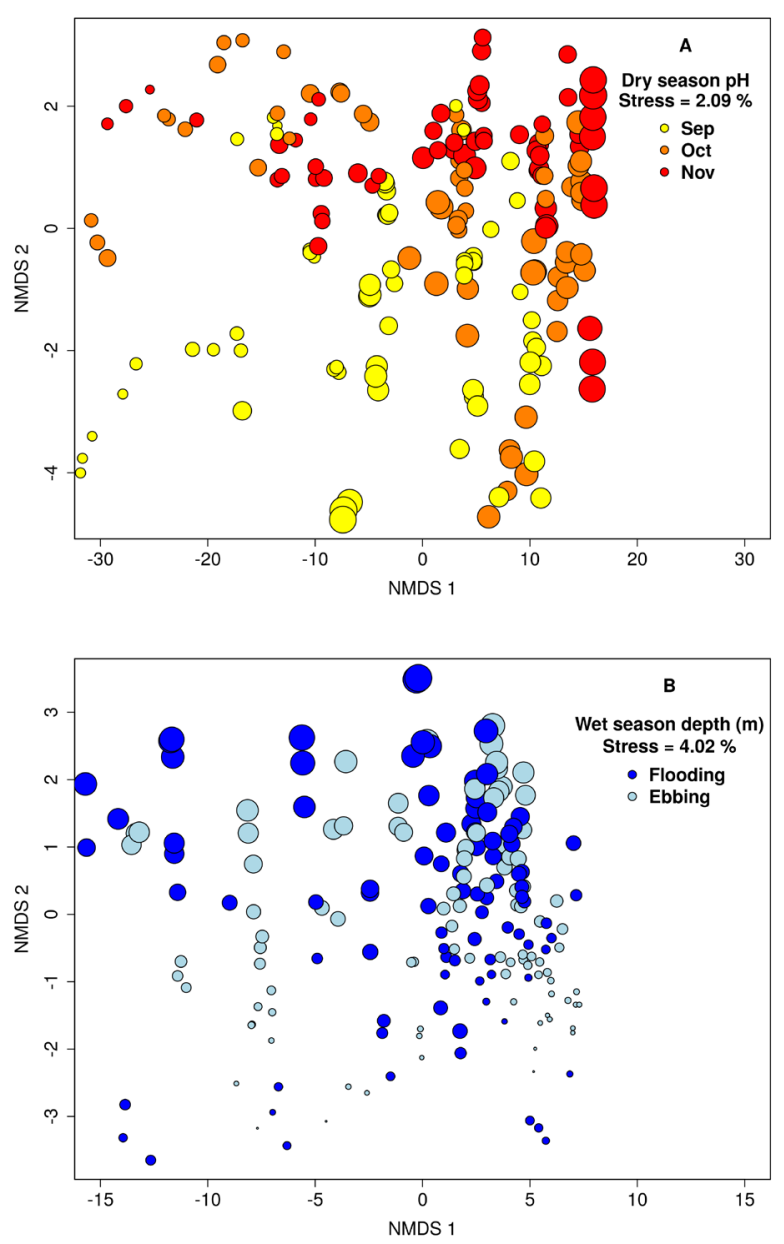

Figure S3. Values of $\mathrm{pH}$ and depth $(\mathrm{m})$ in relation to non-metric multidimensional scaling of culture units (Figure 5) based on values of salinity, temperature $\left({ }^{\circ} \mathrm{C}\right)$, oxidation-reduction potential $(\mathrm{mV}), \mathrm{pH}$, depth $(\mathrm{m})$, and dissolved oxygen ( $\mathrm{mg}$ $\mathrm{I}^{-1}$ ) measured at seven oyster culture units along the Pará coast during the 2013 dry season (September, October and November) (A) and the 2014 wet season (February, March and April) (B). Replicates are coded according to sampling date (month) during the dry season in (A) and tidal state (flooding or ebbing) during the wet season in (B). Diameter of symbols in (A) and (B) is proportional to the value of $\mathrm{pH}$ and depth $(\mathrm{m})$ measured in each replicate, respectively. 